University of Nebraska - Lincoln

DigitalCommons@University of Nebraska - Lincoln

$12-2012$

\title{
MIGRATION ELASTICITIES, FISCAL FEDERALISM, AND THE ABILITY OF STATES TO REDISTRIBUTE INCOME
}

Seth H. Giertz

University of Nebraska-Lincoln, sgiertz2@unl.edu

Mehmet S. Tosum

University of Nevada, Reno, tosun@unr.edu

Follow this and additional works at: https://digitalcommons.unl.edu/econfacpub

Giertz, Seth H. and Tosum, Mehmet S., "MIGRATION ELASTICITIES, FISCAL FEDERALISM, AND THE ABILITY OF STATES TO REDISTRIBUTE INCOME" (2012). Economics Department Faculty Publications. 81. https://digitalcommons.unl.edu/econfacpub/81

This Article is brought to you for free and open access by the Economics Department at DigitalCommons@University of Nebraska - Lincoln. It has been accepted for inclusion in Economics Department Faculty Publications by an authorized administrator of DigitalCommons@University of Nebraska - Lincoln. 


\title{
MIGRATION ELASTICITIES, FISCAL FEDERALISM, AND THE ABILITY OF STATES TO REDISTRIBUTE INCOME
}

\author{
Seth H. Giertz and Mehmet S. Tosun
}

This paper develops a simulation model in order to examine the effectiveness of state attempts at redistribution under a variety of migration elasticity assumptions. Key outputs from the simulation include the impact of tax-induced migration on state revenues, excess burden, and fiscal externalities. With modest migration elasticities, the costs of state-level redistribution are substantial, but state action may still be preferred to a federal policy that is at odds with preferences of a state's citizens. At higher migration elasticities, the costs of state action can be tremendous. Overall excess burden is greater, but this is dominated by horizontal fiscal externalities. Horizontal fiscal externalities represent a cost to the state pursuing additional redistribution, but not a cost at the national level.

Keywords: fiscal federalism, income redistribution, excess burden, deadweight loss, fiscal externalities

JEL Codes: H21, H23, H71

\section{INTRODUCTION}

or several decades, the dominant view among economists was that the ability of state governments to redistribute income is limited, and thus redistribution should be left primarily to the federal government. This view was well articulated by Richard Musgrave (1971, p. 7):

"Policies to adjust the distribution of income among individuals must be conducted on a nationwide basis ... [R] egional measures are self-defeating, as the rich will leave and the poor will move to the more egalitarian-minded jurisdictions. Progressive income taxation at the upper as well as transfers at the lower end of the scale - if substantial in scope - must be uniform within the entire area over which there is a high degree of capital and labor mobility, which means they have to be a function of the national government" (Musgrave, 1971, p.7).

Seth H. Giertz: Department of Economics, University of Nebraska, Lincoln, NE, USA (giertz@unl.edu) Mehmet S. Tosun: Department of Economics, University of Nevada, Reno, NV, USA (tosun@unr.edu) 
Despite this view, state governments continue to use redistributive income taxes (in addition to the federal personal income tax). For example, California has a 10.3 percent top state personal income tax rate, which includes a 1 percent surtax on taxable incomes exceeding $\$ 1$ million. Furthermore, California voters are considering raising their surtaxes by 3 percentage points for those with taxable income exceeding \$1 million and by 5 percentage points for those with taxable income exceeding $\$ 2$ million. While Musgrave (1971), Oates (1972), and others suggest that these policies should be left to the federal government, more recent research raises the possibility of a role for states in redistribution. For example, Gordon and Cullen (forthcoming) note that states may differ in their tastes for redistribution. Gordon and Cullen agree that states are better off having the federal government adopt their preferred redistribution policy. However, if the choice is between state-level policies or a federal policy that deviates from the state's preferred choice, then a role for state-level redistribution may still exist. They find that some state redistribution is likely optimal even with high migration elasticities. The question becomes even more complicated if, as Gordon and Cullen assume, state and federal governments react to each other's policies.

The effectiveness of proposals such as those being considered in California is unclear. Important empirical research both supports Musgrave's argument and raises questions pertaining to the assumptions that are at its foundation. In one case, Feldstein and Wrobel (1998) corroborate Musgrave's argument, finding substantial migration elasticities and roughly full wage capitalization for redistributive state taxes. They use Current Population Data (CPS) for March 1983 and 1989 and find that such taxes are capitalized into wage rates, making attempts by states to redistribute income largely ineffective. However, Leigh (2008) and Young and Varner (2011) reach different conclusions. Leigh (2008) uses a broader range of the CPS data from 1977 to 2002, and does not find clear evidence that redistributive taxes affect interstate migration. He finds that redistributive taxes lead to a more equal distribution of post-tax wages. Young and Varner (2011) also report results that are not consistent with Feldstein and Wrobel's findings. They examine the migration response of top earners using New Jersey's "millionaire" tax that was adopted in 2004 as a policy experiment. They find a very small migration response to that tax change and some reduction in income inequality. ${ }^{1}$

Migration responses to redistributive state policies limit the ability of states to redistribute income in two respects. First, it is the relative elasticities of supply and demand that determine the incidence of a tax or a subsidy. Thus, greater migration responses imply larger labor supply elasticities, which diminish the effect of redistributive taxation on after tax wages. However, another possibility is that wages do not adjust. Instead, sectors that are intensive in high-skilled labor (i.e., the factor of production facing the surtax) may contract, while those intensive in low-skilled labor (i.e., the subsidized fac-

${ }^{1}$ There are also other studies that show some tax-induced migration response, particularly for high-income earners (Bakija and Slemrod, 2004; Kleven et al., 2011; Kleven, Landais, and Saez, 2010), and similarly other studies that point to only a limited tax-induced migration response (Conway and Houtenville, 2001; Duncombe, Robbins, and Wolf, 2003; Liebig, Puhani, and Sousa-Poza, 2007; Conway and Rork, 2008). 
tor) may expand. This is consistent with the Rybczynski (1955) and Stolper-Samuelson (1941) theorems applied to the Heckscher-Ohlin-Samuelson model for international trade. Using this approach, Gordon and Cullen (forthcoming) develop an optimal tax model showing the optimality of state redistributive tax policies, even with federal taxation and migration between states. Second, even without wage responses, migration responses imply fiscal externalities, which can greatly increase the costs to states from redistribution. State redistributive policies, by causing high-income taxpayers to leave and low-income beneficiaries to come to the state, both reduce the state's ability to raise revenue and increase its need to provide benefits.

An important policy question is to what extent such policies are capable of redistributing income given the responsiveness of the tax base both within the states and also across different states through interstate mobility. We do not resolve that question here. Instead we perform simulations showing the implications of a range of migration elasticities on the ability of states to redistribute income. In the next section we take a closer look at the issue of wage capitalization. In Sections III and IV, we present a simulation model and results that show the implications of different migration elasticities for efficiency and fiscal externalities. We construct states with differing tastes for redistribution. We use IRS-SOI tax tables as a starting point of our analysis. Redistribution takes the form of a tax subsidy or a negative income tax. We use a range of migration elasticities to show how they impact the analysis and implications for state versus federal redistribution.

In general, high elasticities imply large efficiency consequences from taxation. However, large migration elasticities have more modest (but for high surtaxes, still substantial) impacts on overall economic efficiency, but large effects on fiscal externalities. The larger the fiscal externalities, the more appealing is federal policy, even if it deviates from the state's preferred policy. For example, consider a state that favors a 10 percent surtax, which may not be desirable at the federal level. With a migration elasticity of 1 , state revenues from the surtax fall by 39 percent (to $\$ 572$ million from $\$ 931$ million under the federal scenario) and the average subsidy falls by 41 percent (from $\$ 1,707$ under the federal scenario to $\$ 1,012$ ). Overall excess burden from the surtax rises by 16 percent (from $\$ 435$ million to $\$ 506$ million). The increase in excess burden is small relative to the drop in revenues because of a $\$ 289$ million fiscal externality, which equals 81 percent of the drop in own state revenues - and also represents gains in state revenues for other states.

By comparison, a federal surtax of 5 percent looks appealing. While far from the state's ideal choice, revenue from the federal tax (earmarked for the state whose citizens contributed the revenues) is not lost to fiscal externalities. By comparison, a 5 percent federal surtax scenario raises $\$ 466$ million for the state or 81 percent of what the 10 percent state tax would raise with a migration elasticity of 1 . The subsidy under the federal plan would be $\$ 855$ or 84 percent of what the 10 percent state tax would raise (with a migration elasticity of 1 ). While the federal numbers are lower than those for the state plan (with twice the surtax rate), the federal plan saves the state $\$ 359$ million, which represents the horizontal fiscal externality from the state plan. For states favoring 
less redistribution and for cases where migration responses are smaller, the advantages of federal taxation are smaller.

\section{TAX-INDUCED MIGRATION AND WAGE CAPITALIZATION}

This section provides a brief overview of the wage capitalization issue before turning to the question of fiscal externalities. In a basic partial equilibrium labor market model, perfect labor mobility gives us full wage capitalization as shown in Figure 1. (Over the long-run, this can be thought of as a perfectly elastic supply curve.) Table 1 shows specific incidence calculations for different migration elasticities with labor supply and labor demand elasticities kept fixed at plausible estimates from the literature. ${ }^{2}$ Again, we see that full wage capitalization where post-tax wage increases by the full amount of the tax occurs when the migration elasticity reaches infinity. While the main arguments and findings in Feldstein and Wrobel (1998) are more in line with Figure 1 or the incidence result shown in the last column of Table 1, the findings in Leigh (2008) and Young and Varner (2011) are more in line with the incidence result shown in the first column of Table 1. Since migration plays a critical role in determining the exact wage capitalization result in this model, we show basic state migration statistics from the CPS and the American Community Survey in Table 2 and Table 3, respectively.

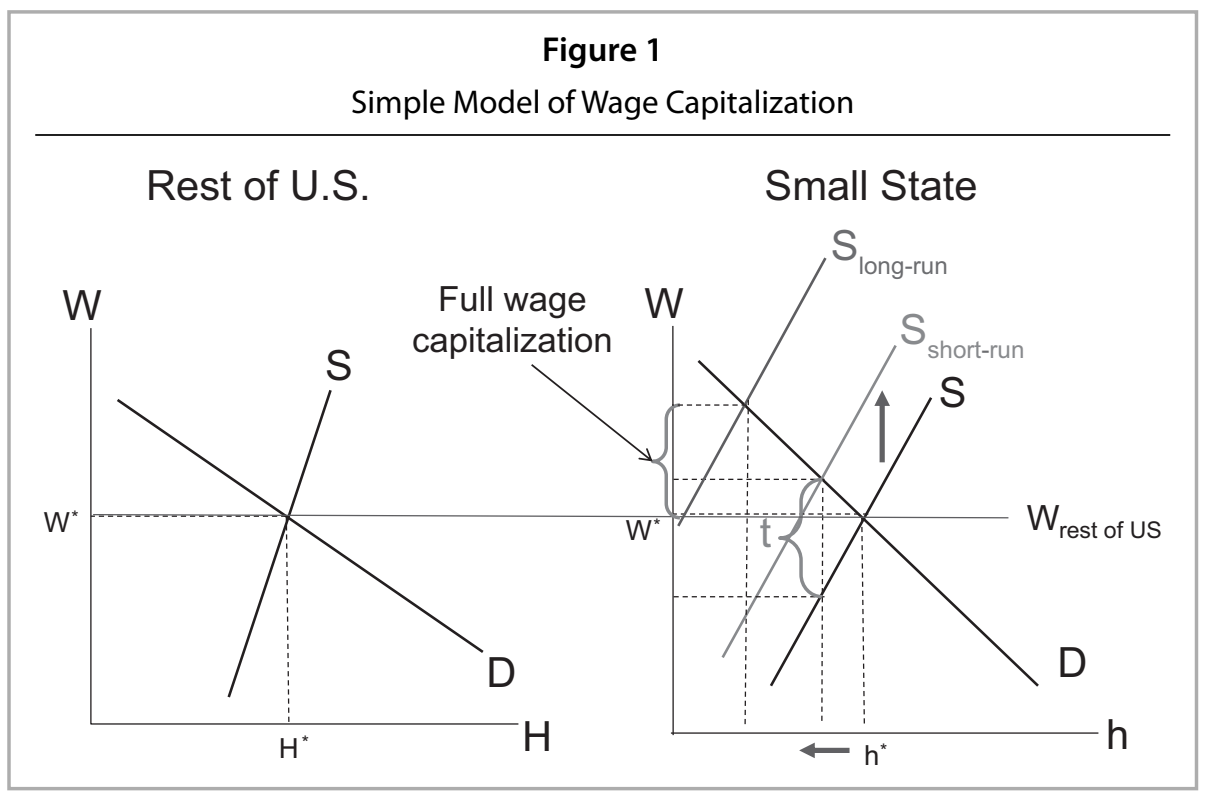

${ }^{2}$ For these calculations we are using the standard partial equilibrium tax incidence formula as follows: $d P / d t=\eta_{D} /\left(\eta_{S}-\eta_{D}\right)$ for a tax paid by consumers, and $d P / d t=\eta_{S} /\left(\eta_{S}-\eta_{D}\right)$ for a tax paid by producers, where $\eta_{D}$ is the price elasticity of demand and $\eta_{S}$ is the price elasticity of supply. 


\begin{tabular}{|lrrrrrrr|}
\hline \multicolumn{7}{c|}{ Table 1 } \\
& Wage Capitalization from Redistributive Taxation & \\
\hline $\mathrm{e}_{\text {migration }}$ & 0.00 & 0.25 & 0.75 & 1.00 & 2.00 & infinity \\
\hline$\eta_{S}$ & 0.10 & 0.10 & 0.10 & 0.10 & 0.10 & 0.10 \\
$\eta_{D}$ & -0.45 & -0.45 & -0.45 & -0.45 & -0.45 & -0.45 \\
Employer share & 0.18 & 0.44 & 0.65 & 0.71 & 0.82 & 0.00 \\
Employee share & -0.82 & -0.56 & -0.35 & -0.29 & -0.18 & 0.00 \\
\hline Source: Authors' calculations & & & & & & \\
\hline
\end{tabular}

Table 2 shows that migration flows do not necessarily increase with income (and in some cases decrease with income) but there is relatively high mobility among the top (\$75,000 and over) income group. The West region that tends to have states with low (or no) income tax has a surprisingly low share of in-migrants and high share of outmigrants for the top income group, whereas the opposite occurs for the Northeast region that has more high-income-tax states. Table 3 shows that there is a high variation in the share of in-migrants in total state population across states but the average share is only slightly greater than 2 percent. Hence it is difficult to say exactly how important or large migration flows are between states. While some states experience particularly high levels of interstate migration, average migration share does not seem to be very high. At the same time, while there is no clear positive association between income groups and migration flows, the top income group, as expected, seems to experience relatively high migration. This provides good motivation to use not one but a set of different migration elasticities in our analysis.

At the same time, and as mentioned in the introduction, wages do not necessarily adjust. Hanson and Slaughter (2002) showed that state factor supply shocks (such as migration) do not lead to state-specific wage adjustments. This is also consistent with the approach used by Gordon and Cullen (forthcoming) and the productivity-adjusted factor price equalization argument.

There does not seem to be a consensus in the relevant empirical literature on whether or to what extent states are able to redistribute income through income taxation, leaving room for more research on the link between redistributive taxes, migration, and the redistributive ability of states. The coexistence of federal and state redistributive taxation is another interesting link that we address in this paper.

\section{MODEL AND DATA}

We develop a simplified model for the United States and then conduct simulations to assess the implications of high-income surtaxes under different scenarios. The analysis relies on aggregated Internal Revenue Service data, which breaks income down by statutory marginal tax rates (Table 4 ). The table excludes income subject to a top tax 


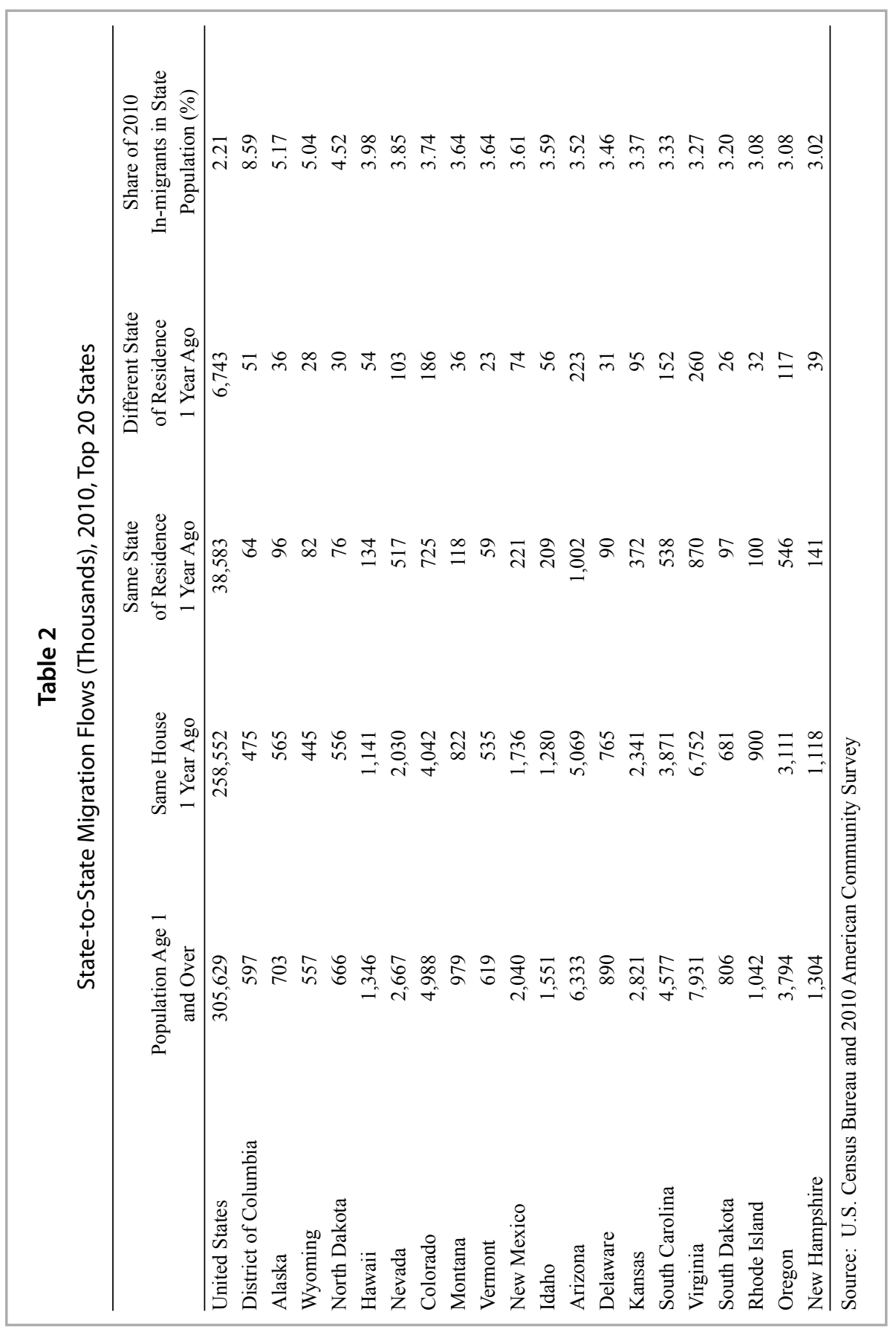




\section{Table 3}

Migration Flows in U.S. Regions, by Income: 2010-2011

\begin{tabular}{|c|c|c|c|c|}
\hline Total in-migrants $(16+$ years, thousands) & $\begin{array}{c}\text { Northeast } \\
188 \\
\end{array}$ & $\begin{array}{c}\text { Midwest } \\
428\end{array}$ & $\begin{array}{c}\text { South } \\
789 \\
\end{array}$ & $\begin{array}{c}\text { West } \\
486 \\
\end{array}$ \\
\hline \multicolumn{5}{|l|}{ In-migration Shares by Income Groups (\%): } \\
\hline Without income & 5.32 & 13.79 & 10.01 & 12.76 \\
\hline Under $\$ 10,000$ or loss & 19.15 & 17.99 & 24.97 & 14.81 \\
\hline$\$ 10,000-\$ 19,999$ & 13.83 & 15.42 & 16.48 & 17.90 \\
\hline$\$ 20,000-\$ 29,999$ & 18.09 & 12.62 & 11.66 & 14.81 \\
\hline$\$ 30,000-\$ 39,999$ & 12.77 & 13.55 & 9.00 & 12.14 \\
\hline$\$ 40,000-\$ 49,999$ & 4.26 & 7.71 & 8.49 & 6.17 \\
\hline$\$ 50,000-\$ 59,999$ & 7.98 & 4.67 & 4.82 & 7.00 \\
\hline$\$ 60,000-\$ 74,999$ & 3.19 & 3.74 & 4.56 & 7.61 \\
\hline$\$ 75,000+$ & 15.96 & 10.98 & 10.39 & 6.38 \\
\hline Total out-migrants ( $16+$ years, thousands) & 408 & 369 & 627 & 487 \\
\hline \multicolumn{5}{|l|}{ Out-migration Shares by Income Groups (\%): } \\
\hline Without income & 13.24 & 8.13 & 13.08 & 9.03 \\
\hline Under $\$ 10,000$ or loss & 20.34 & 19.51 & 17.86 & 23.61 \\
\hline$\$ 10,000-\$ 19,999$ & 15.20 & 17.07 & 14.99 & 18.48 \\
\hline$\$ 20,000-\$ 29,999$ & 13.24 & 13.55 & 15.95 & 9.86 \\
\hline$\$ 30,000-\$ 39,999$ & 11.03 & 8.94 & 12.44 & 11.50 \\
\hline$\$ 40,000-\$ 49,999$ & 9.80 & 6.50 & 7.02 & 6.16 \\
\hline$\$ 50,000-\$ 59,999$ & 1.96 & 10.03 & 5.42 & 5.75 \\
\hline$\$ 60,000-\$ 74,999$ & 5.88 & 5.15 & 4.63 & 4.72 \\
\hline$\$ 75,000+$ & 9.80 & 10.57 & 8.93 & 11.29 \\
\hline
\end{tabular}

Source: U.S. Census Bureau and 2011 Annual Social and Economic Supplement

\section{Table 4}

2005 Individual Income and Tax Revenues by Tax Bracket

\begin{tabular}{lcccc}
\hline $\begin{array}{l}\text { Statutory } \\
\text { MTR (\%) }\end{array}$ & $\begin{array}{c}\text { Taxable Income } \\
\text { \$Millions }\end{array}$ & $\begin{array}{c}\text { Income at MTR } \\
\text { \$Millions }\end{array}$ & $\begin{array}{c}\text { Tax Revenue } \\
\text { \$Millions }\end{array}$ & $\begin{array}{c}\text { Tax Revenue at } \\
\text { MTR \$Millions }\end{array}$ \\
\hline 10 & 152,960 & 145,800 & 14,591 & 14,580 \\
15 & $1,183,128$ & 675,310 & 152,079 & 101,296 \\
25 & $1,568,262$ & 286,224 & 265,214 & 71,556 \\
28 & 545,834 & 46,365 & 115,129 & 12,982 \\
33 & 387,601 & 84,882 & 95,205 & 28,011 \\
35 & 860,237 & 485,043 & 261,691 & 169,765 \\
Total & $4,698,021$ & & 903,909 & \\
\hline
\end{tabular}

Source: Based on Table 3.4 from IRS (2011) 
rate equal to the capital gains rate and also excludes those filers with no income tax liability. For our analysis, it is only the 10 percent and 35 percent brackets that are important. For 2009, the 10 percent bracket applies to taxable income from zero to as high as $\$ 16,700$ (for joint filers). The 35 percent bracket begins at $\$ 372,950 .^{3}$ Table 4 shows $\$ 4.7$ trillion in (modified) taxable income and over $\$ 900$ billion in tax revenue for 2009. These numbers are smaller than 2009 totals because they exclude filers whose top marginal tax rate (MTR) is for income from capital gains. ${ }^{4}$

These data are used to create hypothetical and stylized states. States are assumed to have attributes that are exactly $1 / 50$ of those reported in Table 4 . When accounting for effects occurring outside the state, the rest of the United States is assumed to have attributes that are exactly $49 / 50$ of those reported in Table 4 . While the stylized states are homogeneous with respect to size, income and income distribution, they may have heterogeneous preferences for redistribution.

In the following section, we construct several scenarios. We examine two states that are considering high-income surtaxes on those in the 35 percent federal income tax bracket, with the additional revenue redistributed to those in the 10 percent federal income tax bracket. We compare and contrast these results to those obtained with a purely federal policy. We include three cases: a 3, 5 or 10 percentage point surtax. Next, we examine purely state policies. In one case, a state implements a 3 percentage point surtax. In the other case, a state implements a 10 percentage point surtax. In both instances, the federal and other state governments make no policy changes.

In our model, subsidies to the low-income group are structured similar to the Earned Income Tax Credit. Revenue raised from the surtax on the 35 percent federal tax bracket is used to lower marginal tax rates for those in the 10 percent tax bracket. Note that the per capita value of the subsidy may be influenced by migration patterns (in addition to other behavioral responses) at both the top and bottom of the income distribution. Outmigration from the high-income group lowers the pool of revenue used to subsidize the low-income group. And, in-migration at the low end of the income distribution results in a lower-subsidy rate, since the budget for the program is set by the revenue from the surtax. This EITC-based approach seems consistent with recent trends in redistribution at both the federal and state levels. The EITC is now the largest cash transfer program in the United States that targets low-income groups. Additionally, 25 states plus the District of Columbia supplement the federal program with their own state EITCs (Johnson and Williams, 2011).

An alternative possibility is to provide lump-sum grants to the low-income group. Such a scheme could impact migration, but would not affect work incentives, except for those at the kink point or in the phase-out range. Aside from those at the kink, the lowincome subsidy would not have efficiency implications (emanating from the low-income group). By contrast, the EITC-based approach has positive efficiency implications for the economy by reducing the tax wedge for the low-income group. This partially offsets the welfare loss from the high-income surtax.

\footnotetext{
${ }^{3}$ See IRS (2011), Table 3.4.

${ }^{4}$ Total tax revenue includes some revenue from capital gains taxes, so long as capital gains were taxed at a lower rate than the filers' top rate on ordinary income.
} 


\section{A. Migration and Fiscal Externalities}

Suppose the political process within each state effectively aggregates citizens' preferences (which are heterogeneously distributed across states) into a social welfare function and implements policies accordingly. Then, the state government will transfer income from the top to bottom bracket until the marginal cost including excess burden of the last dollar transferred exactly equals the marginal social benefit, as calculated via the social welfare function. ${ }^{5}$ The surtax imposes costs to society as measured by changes in excess burden. These costs are weighed against the benefits citizens receive from redistributing income and, because the low-income subsidy here is efficiency enhancing, efficiency gains from the low-income subsidy.

Maintaining these assumptions, one would expect the state to optimize the social welfare of its citizens, without regard to the welfare of those in other states. ${ }^{6}$ However, the welfare implications for both the own state and other states will depend, partly, on migration responses to the tax changes. These responses include people physically moving as well as shifting income across state boarders. These migration responses create fiscal externalities, and thus states maximizing their own social welfare will not be optimizing from a national perspective.

Absent externalities, Feldstein $(1995,1999)$ shows that the marginal excess burden associated with another dollar of income leaving the tax base in response to a tax rate increase is reflected by the marginal tax rate. For example, if one's marginal tax rate goes from 35 to 38 percent, the loss to society associated with the last dollar removed from the tax base is 38 cents (i.e., the price the government would have charged had it been reported as taxable income). ${ }^{7}$ However, with migration, some taxable income is not leaving all tax bases, but is shifted from one tax base to another. In this case, it is the difference between the marginal tax rates in the two tax bases that affects the marginal cost of shifting a dollar of taxable income. This income shifting represents a horizontal fiscal externality that benefits other states, partially offsetting the welfare loss to the taxing state. For more on the implications of fiscal externalities, see Saez, Slemrod, and Giertz (2012) and Chetty (2009).

It is these fiscal externalities that underlie the standard arguments made by Musgrave (1971), Oates (1972), and others that redistribution should be primarily left to the federal government. Interstate migration is not an issue with federal policy that applies to all states, thus horizontal fiscal externalities are no longer present. However, there are a couple of important caveats to this argument. Johnson (1988) shows that there is

\footnotetext{
${ }^{5}$ An additional assumption is that citizens are only concerned with the redistribution between these two brackets or that there are other constraints preventing other types of redistribution.

${ }^{6}$ While this model of the political system is highly unrealistic, with respect to both the ability to aggregate preferences and with the motivation of politicians, it is not central to the analysis in the following section. Excess burden and revenue calculations do not depend on the political process used to reach these policies. However, an analogy to a social welfare function is necessary, if one is to assess whether the benefits of the policy outweigh the costs.

${ }^{7}$ Note that this is different from the marginal excess burden associated with another dollar of tax revenue and is also different from the marginal excess burden from increasing the tax rate, which depends the elasticity of taxable income - i.e., how much income leaves the tax base.
} 
also a negative fiscal externality imposed on other states related to changes in federal tax revenues. Own state behavioral responses, other than migration, to a surtax reduce federal revenues. This lowers federal expenditures in the own state (which does not represent an externality), but also reduces federal expenditures (assuming that federal tax rates and borrowing are held constant) in other states. This represents a negative fiscal externality for the other states and acts to offset the positive fiscal externality. Johnson goes on to show that relative sizes of the labor supply - his work predates the taxable income elasticity literature - and migration elasticities are critical in determining the roles that the federal and state governments should play in redistribution. With a purely federal policy, the horizontal fiscal externality is avoided; however, behavioral responses to the federal policy generate negative vertical fiscal externalities.

Gordon and Cullen (forthcoming) also point to a potential role for states in redistribution. They note that states may have different preferences for redistribution - an assumption we have adopted here. With heterogeneous tastes across states, a federal policy avoids horizontal fiscal externalities, but the cost of this policy is that most states do not have their preferred policy with respect to redistribution. Gordon and Cullen develop a sophisticated model that allows for both state and federal roles in redistribution policy. As with Johnson, the size of the migration elasticity is central in determining the balance between federal and state policies.

In what follows, we construct states with differing tastes for redistribution. We estimate the excess burden from such policies and the value of the low-income subsidies. In doing so, we also estimate the implications the policies would have for tax revenues and migration. We produce estimates under an array of migration elasticities, including cases where the policy is carried out at the federal level and migration is not relevant. Our analysis highlights the tradeoffs between efficiency and equity and illustrates the role of positive fiscal externalities raised by Musgrave, Oates, and others, as well as the offsetting vertical fiscal externalities raised by Johnson. By comparing federal and state policies, we also show the tradeoffs between the level of excess burden and the desired policies towards redistribution that are raised by Gordon and Cullen.

\section{B. Model Setup}

As presented in Saez, Slemrod, and Giertz (2012), and building on the work of Feldstein (1999), the change in revenues resulting from an increase in tax rates on the top tax bracket is broken down into mechanical and behavioral changes, such that

$$
\Delta \text { Revenue }=N \cdot \Delta \operatorname{EMTR} \cdot(z-\bar{z}) \cdot\left[1-E T I \cdot\left(\frac{z}{z-\bar{z}}\right) \cdot\left(\frac{E M T R}{1-E M T R}\right)\right]{ }^{8}
$$

\footnotetext{
${ }^{8}$ Tax rate changes at lower brackets can be analyzed analogously by focusing on the group of taxpayers facing the marginal rates in the bracket in which the rate is changing. However, with a tax rate increase there will also be a gain (and with a decrease in the tax rate there will be a loss) in revenues from those with incomes in the higher brackets.
} 
Here, $z$ is average taxable income for those in top rate bracket, and $\bar{z}$ is the level of taxable income where the top tax rate kicks in, and $N$ is the number of taxpayers in the top bracket. EMTR is the effective marginal tax rate. The EMTR - that is, the share of an additional dollar of income that is paid to the government - is often somewhat different from the statutory MTR because the EMTR takes into account phase-ins, phase-outs, and other interactions with the IRS code. These other factors affect the actual share of income that the government receives. ETI is the elasticity of taxable income. The first part of (1), $N \cdot \triangle E M T R \cdot(z-\bar{z})$ equals the mechanical response, or the change in tax revenue assuming no behavioral responses (migration or otherwise). Thus, if ETI equals 0 , there is no behavioral response and tax revenue increases linearly with the tax rate. The second term (i.e., the term inside the brackets) is the share of the mechanical response that is offset by changes in behavior. If this share is greater than 1 , it implies a Laffer response - that is, an increase in the MTR results in a decrease in tax revenue. Note that the Laffer (or revenue maximizing) rate equals $1 /\{1+[z /(z-$ $\bar{z})] E T I\}$. And, that rearranging (1) to highlight revenue changes from the mechanical and behavioral responses yields

(2) $\quad \Delta$ Revenue $=N \cdot \Delta E M T R \cdot(z-\bar{z})-E T I \cdot \Delta E M T R \cdot N \cdot z \cdot\left(\frac{E M T R}{1-E M T R}\right)$,

where the first term is the mechanical response and the second term is the behavioral response, which equals the marginal excess burden.

Finally, the behavioral response is also exactly equal to the change in excess burden resulting from the tax rate change. ${ }^{9}$ However, this is only true so long as this is a holistic measure of tax revenue - i.e., it includes revenue that is lost to one tax base, but is shifted into another tax base. In other words, focusing on a single tax base may provide a poor estimate of excess burden if fiscal externalities are present. If a tax induces migration, and thus affects taxable income in other states, then (2) would need to be analyzed for each state (even if policy remains unchanged in these other states).$^{10}$

The behavioral response from (2) affects overall revenues from the federal, payroll, and state tax bases combined because the bases overlap. One can impute average income, $z^{\prime}$, at the new tax rates where

$$
z^{\prime}=z \cdot\left(1-E T I \cdot\left(\frac{d t}{1-M T R}\right)\right)
$$

Next the overall change in revenues can be disaggregated into changes in revenues for each of the taxes with overlapping tax bases. Thus, the change in state income tax

\footnotetext{
${ }^{9}$ For more detail on how these responses are calculated, see Saez (2004) or Saez, Slemrod, and Giertz (2012).

${ }^{10}$ In terms of notation, this would mean summation signs to both sides of (2) and adding subscripts to denote each state.
} 
revenue from raising the rate on the top income tax bracket, and when accounting for behavioral responses, can be expressed such that

(4) $\Delta$ StateRevenue $=N \cdot\left(\Delta E M T R \cdot\left(z^{\prime}-\bar{z}\right)-\operatorname{EMTR}_{\text {state }} \cdot\left(z-z^{\prime}\right)\right)$.

As discussed earlier in this section, Table 4 provides the information on taxable income and taxpayers by federal tax bracket, which will be used with the formulas just presented. To carry out the exercise, information or assumptions are needed for EMTRs and for the ETI. We use EMTRs on labor income estimated by the Congressional Budget Office (CBO, 2005). ${ }^{11}$ According to $\mathrm{CBO}$ and as presented in Table 5, when all the intricacies of the tax code are taken into account, EMTRs for the individual income tax range from -1.6 percent for those not paying income tax but sometimes receiving refundable tax credits (such as the earned income tax credit), to almost 35 percent for the top two statutory tax brackets. The remaining columns of Table 5 show what happens when payroll and state taxes are also included. While the individual income tax hits upper income groups the hardest (at the margin), federal payroll taxes (used to finance Social Security and Medicare) hit lower income groups the hardest. EMTRs for state taxes are greatest for middle-income groups. When these three taxes are combined, EMTRs range from just over 30 percent for the 10 percent bracket to over 41 percent for the 33 percent bracket. ${ }^{12}$

\begin{tabular}{|lcccc|}
\hline \multicolumn{5}{c}{ Table 5 } \\
& Effective Marginal Tax Rates & \\
\hline Statutory Tax & Federal & Payroll & State & Total \\
Rate Bracket & EMTR & EMTR & EMTR & EMTR \\
\hline 0 & -1.6 & 13.5 & 0.9 & 12.7 \\
10 & 14.8 & 12.8 & 2.6 & 30.2 \\
15 & 16.3 & 12.5 & 6.1 & 34.9 \\
25 & 26.3 & 10.0 & 3.7 & 40.0 \\
28 & 30.1 & 5.3 & 3.7 & 39.0 \\
33 & 34.7 & 3.1 & 3.5 & 41.3 \\
35 & 34.7 & 2.5 & 3.4 & 40.7 \\
\hline Source: Congressional Budget Office (2005) & & & \\
\hline
\end{tabular}

${ }^{11}$ See CBO (2005) for an analysis of EMTRs on labor income. CBO's analysis is after the Jobs and Growth Tax Relief Reconciliation Act (JGTRRA) of 2003, which approximates the current U.S. Federal income tax system.

${ }^{12}$ Note that EMTRs and statutory MTRs can be very different from average tax rates, which simply represent total taxes divided by total income. For an analysis of average income tax rates across income groups and over time, see Piketty and Saez (2007). 
The final piece of information is the ETI. At the national level, the empirical literature on the ETI suggests a wide range of plausible estimates, and considerable disagreement surrounds the size of this parameter (Saez, Slemrod, and Giertz, 2012). One general finding from the literature, however, is that responsiveness tends to be larger for highincome taxpayers. Excluding migration effects, we assume a base ETI for the top income group of 0.4. For the low-income group, we assume a base ETI of 0.25 . These are used to estimate the effects of federal tax changes, where migration is not an issue. To highlight the effect of migration elasticities on the analysis, we perform simulations with a migration ETI of 0.3 and again with a migration ETI of 1 (as well as the federal case, where we assume the migration ETI is 0 ). The overall ETI is assumed to equal the base ETI plus the migration ETI. ${ }^{13}$

Taxes may affect migration and other taxable income responses in different ways. It is usually argued that the marginal tax rate is the central motivating factor underlying the ETI. However, it may be that average tax rates are more important when considering migration. For example, if one is considering where to locate and cannot easily shift dollars across state lines at the margin, then the marginal tax rate may be a second order consideration. An increase in one's marginal tax rate, coupled with a lowering of rates in other brackets, could have the net effect of increasing one's after-tax income (absent behavioral responses). Thus, people may base location more on average tax rates, but the marginal tax rate would influence behavior once relocated. While we find this argument appealing, for the sake of simplicity, we continue to focus on the marginal tax rate as the driving force behind tax responses, including migration.

\section{RESULTS}

Results from the exercise described in the previous section and presented here show that migration responses have relatively modest effects on the overall excess burden, but can introduce substantial fiscal externalities. Employment in a different state may be a close substitute to employment in one's own state, and the closer the substitutes, the lower the overall efficiency loss. This is analogous to Harberger's (1964) comprehensive excess burden formula. Harberger shows that for a positive tax rate (and a given overall elasticity), substitutes to the taxed good lessen the overall excess burden, while complements exacerbate the effect. The core ETI (i.e., excluding migration responses), on the other hand, is central to determining the overall excess burden from the surtaxes. Migration responses, by imparting fiscal externalities, can create huge differences between the overall (national) excess burden from a surtax and the burden borne by the state enacting the policy. The migration responses also greatly lower the states' ability to provide subsidies. For the 3 percent surtax, migration responses lower the average subsidy by 8 percent with a migration elasticity of 0.3 , and by 20 percent

\footnotetext{
${ }^{13}$ Recall from Section II that when examining wage capitalization, we assumed a labor supply elasticity of 0.1 . The ETI is a broader measure of tax responsiveness and traditional labor supply responses are just one component of the ETI.
} 
with a migration elasticity of 1 . For the 10 percent surtax migration responses lower the average subsidy by 19 percent with a migration elasticity of 0.3 , and by 41 percent with a migration elasticity of 1 .

\section{A. Federal Case}

Tables 6 and 7 depict results from the federal redistributive tax plans for three possible surtax rates. To facilitate comparisons to state policies, we assume here that, instead of a federal surtax, all states impose the exact same surtax and redistribution scheme. Thus, revenues from the surtax are labeled state revenues. This approach is identical to a federal policy in which the revenues from the surtax are given back to the states or earmarked for redistribution. Because the policy applies to all states, for a given plan, the surtax and low-income subsidy is identical for each state.

The numbers in Tables 6 and 7 are all driven by the assumption of an ETI of 0.4 (with no migration) for the top federal income tax bracket and an ETI of 0.25 for the low-income group. While these are reasonable assumptions, there is no consensus in the literature. Credible estimates range from 0 to 1 - and some studies report estimates in excess of 1 for very high-income groups. Where the ETI lies within this wide range of estimates has tremendous consequences for the efficiency and revenue implications from changes to tax rates. In fact, in examining the major components of the "Bush tax cuts," Giertz (2009) uses a range of ETI estimates from the literature to show how allowing the individual income tax rate cuts to expire might affect economic efficiency and tax revenues. Giertz finds the excess burden per additional dollar of tax revenue from the increase in federal income tax rates to range from $\$ 0.19$ at an ETI of 0.2 to $\$ 1.72$ at an ETI of 0.8 - i.e., an ETI of 0.8 implies nine times the deadweight loss (per dollar of additional federal revenue) than does an ETI of $0.2 !^{14}{ }^{15}$ Giertz estimates that an ETI of 0.8 implies a total revenue offset of 63.3 percent versus 15.8 percent at an ETI of 0.2 (both compared to the potential gain in federal revenues with no behavioral responses). Here we do not vary the core elasticities, but examine the implications of assuming different migration elasticities.

At a 5 percent rate, our prototypical state subsidizes the low-income group by an average of $\$ 839$. The per-taxpayer cost for the high-income group is $\$ 29,523$. Each state raises an additional $\$ 466$ million from the high-income surtax. The mechanical change in tax revenue, i.e., had there been no behavioral responses, is $\$ 485$ million. Additionally, behavioral responses lower federal income and payroll tax receipts by a total of $\$ 189$ million (per state). Thus, the excess burden from this tax is $\$ 208$ million

${ }^{14}$ For comparison, Feldstein (1999) uses a microsimulation model to assess the implications of a 10 percent increase in marginal tax rates. He concludes that, assuming an ETI of 1.04, behavioral responses would erase over two-thirds of the mechanical gain in tax revenues and that the marginal excess burden would be over $\$ 2$ per every additional dollar of revenue. In a more recent paper, Feldstein (2008) assumes an ETI of 0.4. Here he reports a marginal excess burden of $\$ 0.76$ per additional dollar of revenue raised.

${ }^{15} \mathrm{At}$ an ETI of 0 , this measure equals 0 (i.e., changes to tax rates have no efficiency implications) and once the revenue-maximizing (or Laffer) tax rate is reached, this measure equals infinity. 


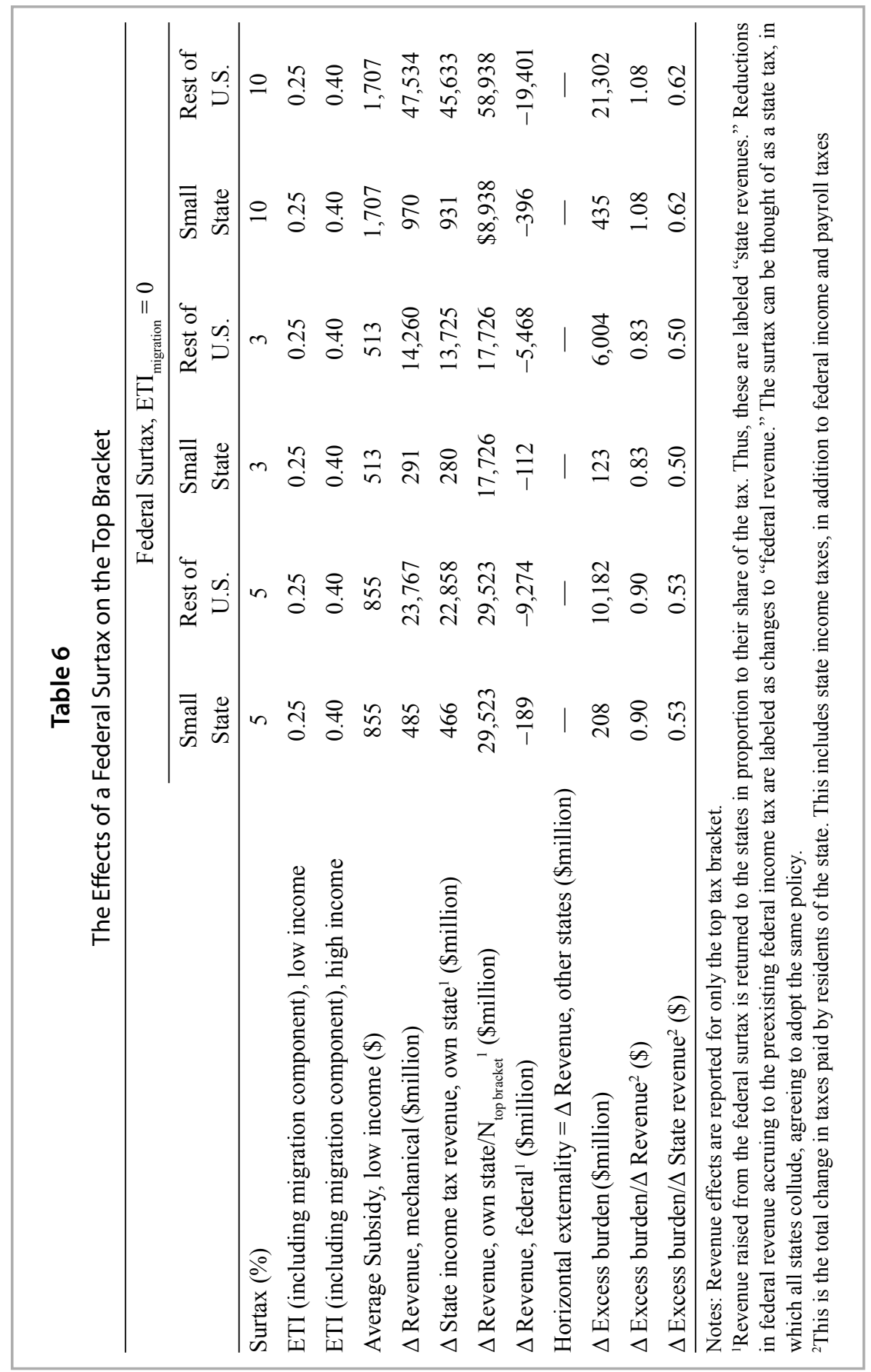




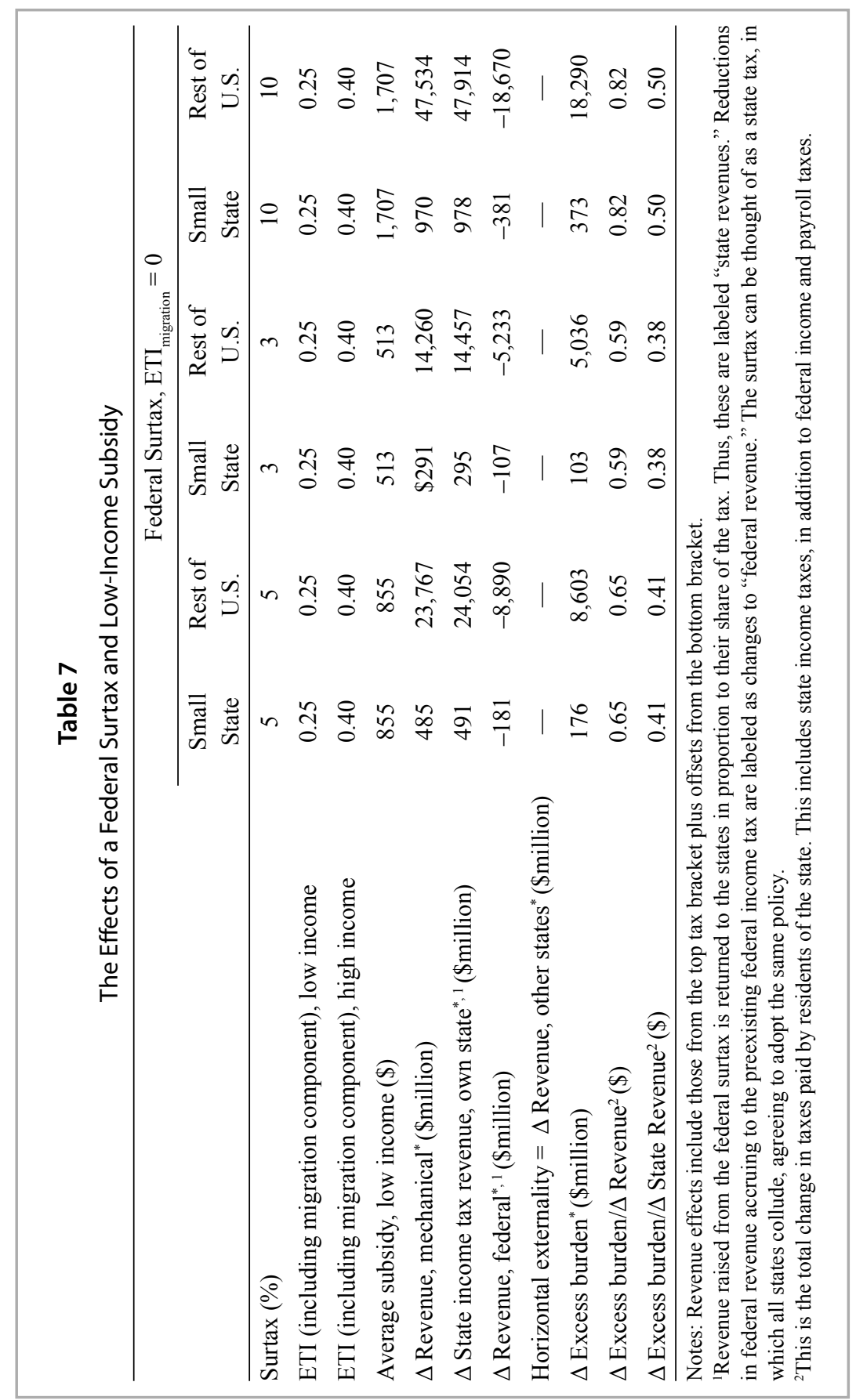


per state. Recall from the previous section that the excess burden equals the mechanical change in revenues minus the actual change. The excess burden per dollar of additional revenue is 90 cents, meaning that for each additional dollar of tax revenue, society loses an additional 90 cents.

However, a state may discount reductions in federal tax revenues that are a byproduct of the tax, since most of this loss will be felt in other states (98 percent of the loss if federal spending is proportional to state population). Thus, from the state's perspective, the loss is 53 cents per additional dollar in state revenue. The remaining 37 cents per dollar is a vertical externality, whose costs are primarily borne by other states. Because this is a federal policy (or all states are adopting the same policy), each state's loss in federal spending would equal its loss in federal tax liabilities. Thus, an optimally behaving state would consider the full cost of the federal policy.

Results from a lower federal surtax ( 3 percent) and a higher federal surtax (10 percent) are also presented in Table 6 . When lowering the federal surtax to 3 percent, the low-income subsidy changes proportionally, falling from $\$ 839$ per taxpayer to $\$ 513$. Raising the surtax to 10 percent raises the low-income subsidy to $\$ 1,707$, or double the 5 percent scenario. Likewise, changes to mechanical revenue and state income tax revenue are also proportional to the tax change. However, total revenue from all sources rises at a less than proportional rate. And, as the surtax rate rise, the marginal excess burden increases at a faster rate than the surtax. For example, while the marginal excess burden is $\$ 208$ million (per state) at the 5 percent rate, the same measure is $\$ 123$ million with a 3 percent surtax and $\$ 435$ million with a 10 percent surtax.

Table 6 only reports excess burden and revenue changes for the top tax bracket. This highlights the effect of the surtax, without regard to the structure of the subsidy. As discussed in the previous section, the subsidy is structured so as to be efficiency improving, although subsidies could be constructed in ways that detract further from efficiency. Table 7 adds the effect of the behavioral changes occurring within the lowincome group. The ETI (excluding migration responses) is assumed to equal 0.25 for this group. In terms of state income tax revenue, behavioral responses allow states to recoup more than 5 percent of the programs costs. ${ }^{16}$ Thus, for the 5 percent surtax, the total effect on state income tax revenues is an increase of $\$ 491$ million, with $\$ 466$ million from the surtax and \$24 million from behavioral responses among the low-income group. ${ }^{17}$ With respect to federal revenues, responses from the low-income group recoup between $\$ 5$ million (4.3 percent of the loss from the top bracket) and $\$ 15$ million dollars (3.8 percent of the loss from the top bracket). Including the efficiency gains from the low-income group substantially lowers the overall excess burden from the surtax. For the 3 percent surtax, responses from the low-income group recoup $\$ 20$ million in excess burden (per state), or 16.1 percent of the measure for the surtax alone. For the 10 percent surtax, reducing the distortion between taxable and non-taxable activities

\footnotetext{
${ }^{16}$ For purposes of calculation, revenues from the low-income group are based on taxes paid prior to (as opposed to net of) the subsidy.

${ }^{17}$ In this and other instances, numbers may not add up exactly due to rounding.
} 
for the low-income group lowers overall excess burden by $\$ 61$ million (per state), or 14.1 percent of the measure for the surtax alone.

\section{B. State Versus Federal Redistribution}

We now turn our attention to redistribution at the state level, assuming that the federal government and other states do not amend their policies in response to the state's actions. We consider two states. One state favors the 10 percent federal surtax; another favors the 3 percent surtax. We compare the implications from a state acting alone to its preferred policy carried out at the federal level, as well as other federal alternatives.

In each case, the state is better off if its preferred policy is carried out at the federal level, and the state policy is more costly and less effective as the migration elasticity increases. Table 8 reports that, with a migration elasticity of 0.3 , a state surtax of 3 percent yields an average low-income subsidy of $\$ 472$ or 92 percent of the $\$ 513$ subsidy under the identical federal plan. A migration elasticity of 1 lowers the subsidy further to $\$ 416,81$ percent of the value under the federal plan. State income tax revenues from the 3 percent surtax fall from $\$ 280$ million under the federal plan to $\$ 258$ million with the state plan and a migration elasticity of 0.3 . With a migration elasticity of 1 , state income tax revenue increases decline further, to $\$ 228$ million. These revenue losses, compared to the federal baseline scenario, are largely offset by revenue gains in other states. ${ }^{18}$ Thus, within state behavioral responses lower taxable income, reducing revenue gains from the surtax. Migration responses shift revenues from the own state to other states. From the state's perspective, both responses have the same consequences, but the consequences are very different from a national perspective; hence, the horizontal fiscal externality.

What are the implications from a federal policy that deviates from the state's most preferred choice? The federal policy eliminates fiscal externalities and allows for a larger subsidy for any given surtax. However, the state's citizens prefer different level of redistribution than the federal government imposes. Compare the state 3 percent surtax results from Table 8 to the 5 and 10 percent federal surtax results from Tables $6 .{ }^{19}$ While the state prefers the 3 percent federal surtax, the federal 5 percent surtax may be preferred to a 3 percent surtax imposed by the state. The moderate surtax state would pay low-income taxpayers a $\$ 855$ dollar average subsidy under the 5 percent federal surtax versus $\$ 472$ under the 3 percent state surtax and a 0.3 migration elasticity. Revenues (per state) raised from the federal tax would equal $\$ 466$ million versus $\$ 258$ million with the lower state tax (and a 0.3 migration elasticity). However, with the state policy, the state would also lose \$21 million from horizontal fiscal externalities. With a migration elasticity of one, the horizontal fiscal externalities rise to $\$ 48$ million and the

${ }^{18}$ This assumes that the taxing state is small relative to the nation and that states are homogeneous in other respects.

${ }^{19}$ Tables 7 and 9 present analogous results accounting for low-income behavioral responses. Here the focus is on the high-income group - although responses by the low-income group do affect the average subsidy. 


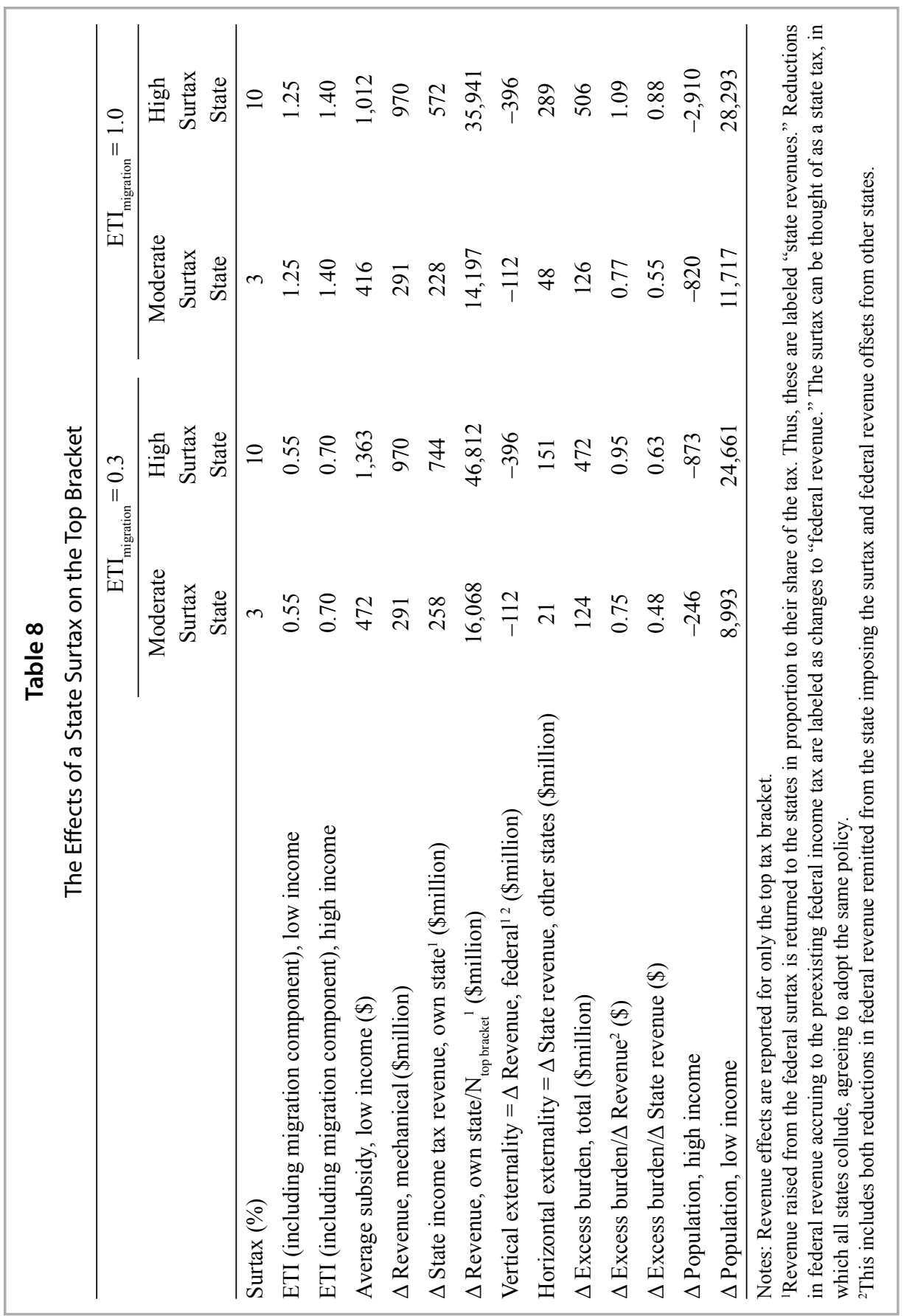


average subsidy falls to $\$ 416$ (for the 3 percent state surtax). The higher the migration elasticity, the better the federal policy looks to the state - even if the federal policy is not the state's most preferred option.

For a state favoring a higher surtax, the negative effects of state action increase substantially. With a migration elasticity of 0.3 , revenue from the 10 percent state surtax drops from $\$ 931$ million (under the federal scenario) to $\$ 744$ million. The low-income subsidy falls from an average of $\$ 1,707$ to $\$ 1,363$. With a migration elasticity of one, revenues from the surtax fall to $\$ 572$ million and the average subsidy falls to $\$ 1,012$. A federal surtax of 5 percent looks appealing by comparison. While it is far from the state's ideal choice, revenue from the tax is not lost to fiscal externalities. The 5 percent federal scenario raises $\$ 466$ million for the state or 81 percent of what the 10 percent state tax would raise with a migration elasticity of 1 . The subsidy under the federal plan would be $\$ 855$ or 84 percent of what the 10 percent state tax would raise (with a migration elasticity of 1). While the federal numbers are lower than those for the state plan (with twice the surtax rate), the federal plan saves the state $\$ 359$ million - including \$289 million, which represents the horizontal fiscal externality or the revenue that would have been recouped by other states.

Like Table 6, Table 8 only reports the revenue and efficiency implications due to the characteristics and behavior of those in the top tax bracket. Table 9 reports the overall results from the state plans, after taking into account the behavioral changes for the low-income group. Because the subsidy is structured to enhance efficiency for the lowincome group, their responses partially offset revenue and efficiency losses from the high-income group. Again, these revenue gains from the low-income are pre-subsidy (as opposed to net-of-subsidy). For the 10 percent state surtax and with a migration elasticity of 0.3 , responses from the lower-income group yield an additional $\$ 60$ million in state revenue, offsetting 27 percent of state revenue losses due to behavioral responses. With a migration elasticity of 1 , the revenue gain is $\$ 55$ million or 14 percent of the revenue losses from behavioral responses by those in the high-income group.

\section{Tax Migration and Fiscal Externalities}

The total excess burden from the surtax is a function of the core ETI (i.e., excluding migration), migration responses, and the size of the surtax. Migration elasticities increase the overall excess burden of a tax, but often have a much larger effect on fiscal externalities. Recall that a core ETI of 0.4 for the high-income group is assumed throughout. With the federal surtax, behavioral responses yield an excess burden but no fiscal externalities. Moving to a migration elasticity of 0.3 , the overall excess burden rises slightly from $\$ 123$ million to $\$ 124$ million. However, the cost to the state is 18 percent larger due to the $\$ 21$ million horizontal externality. ${ }^{20}$ Additionally, federal payroll and income tax revenues are lower by $\$ 112$ million. This includes revenue losses from

${ }^{20}$ The story is somewhat more complex, as the state also loses economic activity and tax revenue as a result of out-migration. However, it also ends up with fewer citizens to provide with public benefits. 


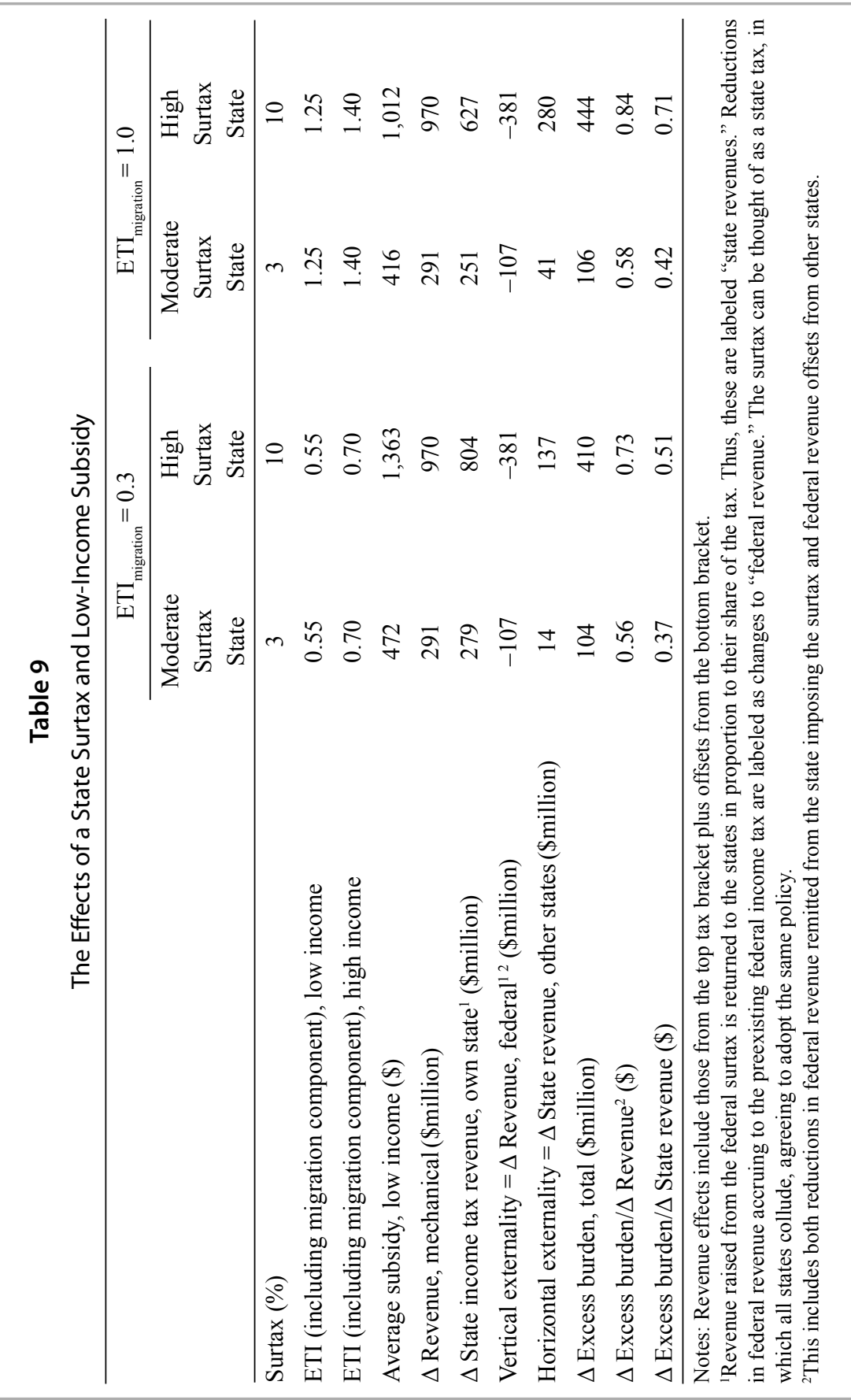


behavioral responses and migration from those initially residing in the state, plus gains in federal revenues in other states. The drop in federal revenues represents a negative vertical fiscal externality. Because some of this lost federal revenue would benefit the taxing state, this effect adds to the state's cost from the surtax. However, the state will heavily discount these costs in making decisions, since most of this burden will be borne by those in other states.

Imposing a migration elasticity of 1 has a larger effect on overall excess burden, but dramatically increases the horizontal fiscal externalities. With the 3 percent surtax, the horizontal fiscal externality (i.e., state income tax revenue shifted to other states) rises from $\$ 21$ million to $\$ 48$ million. For the 10 percent surtax, horizontal fiscal externality rises from $\$ 151$ to $\$ 289$ million. Vertical externalities, from reductions in federal revenues, are driven by the core ETI and are not impacted by migration responses. As noted earlier, horizontal fiscal externalities are analogous to substitute goods in Harberger's (1964) comprehensive excess burden formula. With respect to consumption, a reduction in consumption of a good whose tax is raised imparts smaller efficiency losses if that reduction is accompanied by increased consumption of a close substitute. Likewise, a reduction in economic activity in a state imposing a surtax imparts smaller efficiency losses if economic activity is shifted to a state that is a close substitute. ${ }^{21}$

\section{CONCLUSION}

Since at least Musgrave (1971) and Oates (1972), it has been argued that tax-induced migration severely hinders state attempts at redistribution, and this function of government should thus be administered at the federal level. Nevertheless, states continue to engage in redistribution. Furthermore, results from recent research on the relationship between taxes and migration are mixed, with some studies suggesting that tax-induced migration may be fairly small. Additionally, even if state-level redistribution is less effective than federal action, a role for state governments may remain if tastes for redistribution vary substantially across states.

This paper develops a simulation model that is used to examine the effectiveness of state attempts at redistribution under a variety of migration elasticity assumptions. Key outputs from the simulation include the impact of tax-induced migration on state revenues, excess burden, and fiscal externalities. With modest migration elasticities, the costs of state-level redistribution are substantial, but state action may still be preferred to a federal policy that is at odds with preferences of a state's citizens. At higher migration elasticities, the costs of state action can be tremendous. Overall excess burden is greater, but this is dominated by horizontal fiscal externalities. Horizontal fiscal exter-

${ }^{21}$ The per dollar marginal excess burden equals the difference in marginal tax rates between the two states. By contrast, if activity is shifted to the untaxed black market, the marginal cost per dollar shifted would equal the marginal tax rate in the own state. In this case, economic activity is shifted outside all tax bases. While output may not be affected, it is assumed that the cost of shifting an additional dollar of economic activity to the black market is associated with a cost equal to the marginal tax rate. Otherwise, theory suggests that the activity would have been underground to begin with. Costs include expected penalties from law enforcement as well as any added costs of doing business. 
nalities represent a cost to the state pursuing additional redistribution, but not a cost at the national level. For example, with a migration elasticity of 0.3 , a 3 percent surtax increases overall excess burden by just 1 percent (compared to a case where the federal government implements the identical policy). However, because of horizontal fiscal externalities, the welfare loss to the state imposing the surtax increases by 18 percent. For higher surtaxes and higher migration elasticities, these effects are magnified. With a 10 percent surtax, overall excess burden rises by 8 percent (again compared to identical federal policy) and the burden borne by the state imposing the surtax rises by 43 percent. With a migration elasticity of 1 , these numbers roughly double.

\section{REFERENCES}

Bakija, Jon, and Joel Slemrod, 2004. "Do the Rich Flee from High State Taxes? Evidence from Federal Estate Tax Returns." NBER Working Paper No. 10645. National Bureau of Economic Research, Cambridge, MA.

Chetty, Raj, 2009. "Is the Taxable Income Elasticity Sufficient to Calculate Deadweight Loss: The Implications of Evasion and Avoidance.” American Economic Journal: Economic Policy 1 (2), 31-52.

Congressional Budget Office, 2005. Effective Marginal Tax Rates on Labor Income, Congressional Budget Office, Washington, D.C.

Conway, Karen S., and Andrew J. Houtenville, 2001. "Elderly Migration and State Fiscal Policy: Evidence from the 1990 Census Migration Flows." National Tax Journal 54 (1), 103-123.

Conway, Karen S., and Jonathan C. Rork, 2008. "Income Tax Preferences for the Elderly." Public Finance Review 36 (5), 523-562.

Duncombe, William, Mark Robbins, and Douglas A. Wolf, 2003. "Place Characteristics and Residential Location Choice Among the Retirement-Age Population." The Journals of Gerontology: Series B 58 (4), 244-252.

Feldstein, Martin S., 1995. "The Effect of Marginal Tax Rates on Taxable Income: A Panel Study of the 1986 Tax Reform Act.” Journal of Political Economy 103 (3), 551-572.

Feldstein, Martin S., 1999. "Tax Avoidance and the Deadweight Loss of the Income Tax.” Review of Economics and Statistics 81 (4), 674-680.

Feldstein, Martin S., 2008. "Effects of Taxes on Economic Behavior.” National Tax Journal 61 (1), 131-139.

Feldstein, Martin S., and Marian Vaillant Wrobel, 1998. "Can State Taxes Redistribute Income?" Journal of Public Economics 68 (3), 369-396.

Giertz, Seth H., 2009. "The Elasticity of Taxable Income: Influences on Economic Efficiency and Tax Revenues, and Implications for Tax Policy." In Viard, Alan D. (ed.), Tax Policy Lessons from the 2000s, 101-136. AEI Press, Washington, D.C.

Gordon, Roger H., and Julie B. Cullen, forthcoming. "Income Redistribution in a Federal System of Governments." Journal of Public Economics. 
Hanson, Gordon H., and Matthew J. Slaughter, 2002. "Labor-Market Adjustment in Open Economies Evidence from U.S. States.” Journal of International Economics 57 (1), 3-29.

Harberger, Arnold, 1964. “The Measurement of Waste.” American Economic Review 54 (3), 58-76.

Internal Revenue Service, 2011. "Individual Income Tax Returns 2009 - Publication 1304." Statistics of Income, Internal Revenue Service, Washington, D.C.

Johnson, Nicholas, and Erica Williams, 2011. A Hand Up: How State Earned Income Tax Credits Help Working Families Escape Poverty in 2011. Center on Budget and Policy Priorities, Washington, D.C.

Johnson, William R., 1988. "Income Redistribution in a Federal System.” American Economic Review 78 (3), 570-573.

Kleven, Henrik J., Camille Landais, and Emmanuel Saez, 2010. "Taxation and International Migration of Superstars: Evidence from the European Football Market." NBER Working Paper No. 16545. National Bureau of Economic Research, Cambridge, MA.

Kleven, Henrik J., Camille Landais, Emmanuel Saez, and Esben Schultz, 2011. "Taxation and International Migration of Top Earners: Evidence from the Foreigner Tax Scheme in Denmark." Unpublished manuscript. University of California, Berkeley, CA.

Liebig, Thomas, Patrick A. Puhani, and Alfonso Sousa-Poza, 2007. "Taxation and Internal Migration - Evidence From The Swiss Census Using Community-Level Variation in Income Tax Rates." Journal of Regional Science 47 (4), 807-836.

Leigh, Andrew, 2008. “Do Redistributive State Taxes Reduce Inequality?” National Tax Journal $61(1), 81-104$.

Musgrave, Richard A., 1971. "Economics of Fiscal Federalism." Nebraska Journal of Economics and Business 10 (4), 3-13.

Oates, Wallace E., 1972. Fiscal Federalism. Harcourt Brace Jovanovich, New York, NY.

Piketty, Thomas, and Emmanuel Saez, 2007. "How Progressive is the U.S. Federal Tax System? A Historical and International Perspective.” Journal of Economic Perspectives 21 (1), 3-24.

Rybczynski, Tadeusz M., 1955. "Factor Endowment and Relative Commodity Prices." Economica 22 (88), 336-341.

Saez, Emmanuel, 2004. "Reported Incomes and Marginal Tax Rates, 1960-2000: Evidence and Policy Implications." In Poterba, James (ed.), Tax Policy and the Economy, Volume 18, 117-173. MIT Press, Cambridge, MA.

Saez, Emmanuel, Joel Slemrod, and Seth H. Giertz, 2012. "The Elasticity of Taxable Income with Respect to Marginal Tax Rates: A Critical Review.” Journal of Economic Literature 50 (1), 3-50.

Stolper, Wolfgang F., and Paul A. Samuelson, 1941. "Protection and Real Wages." Review of Economic Studies 9 (1), 58-73.

Young, Cristobal, and Charles Varner, 2011. "Millionaire Migration and State Taxation of Top Incomes: Evidence from a Natural Experiment.” National Tax Journal 64 (2, Part 1), 255-284. 